\title{
Building Empathy
}

\section{Exploring Digital Native Characteristic to Create Learning Instruction for Learning Computer Graphic Design}

\author{
https://doi.org/10.3991/ijet.v15i20.14311 \\ Siti Nurannisaa P.B. $\left(^{(}\right)$ \\ Universitas Negeri Surabaya, Surabaya, Indonesia \\ Universitas Tarumanagara, Jakarta, Indonesia \\ siti.17070996001@mhs. unesa.ac.id \\ Mustaji, Bachtiar S. Bachri \\ Universitas Negeri Surabaya, Surabaya, Indonesia \\ Florens Debora Patricia \\ Universitas Dinamika, Surabaya, Indonesia
}

\begin{abstract}
Technology leads to massive changes, including in the way of learning. As digital natives, students have different ways of learning, especially in courses that use technological devices, such as computers graphic design. Exploring information by building empathy from a student's perspective, can give more authentic information and find opportunities for designing a better learning instructional. The purpose of this study is to explore student's characteristics by building empathy towards students, finding their specific needs and criteria of creating learning instructional that are more need-based. This is a qualitative research, using case study through interviews, focused group discussion and an instrument of empathy map with a qualitative descriptive analysis technique. Study shows that building empathy has the opportunity to prevent the failure of creating learning instruction. Involving students can help to gather the latest information related to their learning needs. The result indicates that students have no difficulty in accessing and using complex technology, this is in accordance with their characteristics as digital native. Students not only need to learn technical capabilities, but also need to develop the ability to operate software in design practices. This is where other study skills related to being a designer for students are needed. Building empathy brings positive impact to find new learning objectives and create learning instructions. These findings suggest following future research on instructional learning that stimulate student's ability that concentrate on designer's skills in their future.
\end{abstract}

Keywords-Empathy, students characteristic, computer graphic, learning instruction, graphic design, design. 


\section{Introduction}

Today's students are different. Their learning habits, the way to access and spread information, methods of socializing, and much more, have been revolutionized by the increasing of information and digitization. Technology leading to massive changes, in the way to communicate and relate to each other, and increasingly in the way of learning [1]. As digital natives, students are more sophisticated in their usage of internet, mobile phones, and devices. They often use technology products and have no difficulty in using complex technology products [2]. Digital native tend to communicate using visual images, such as pictures or videos [3], fulfill their desires using the fastest way [4], multitasks using information and communication technologies such as internet [5], find information and answer their questions in just a few seconds. This young generation has received a large amount of digital input. Therefore, they have different ways of learning and performing, especially in courses that use technological devices, such as computers graphic.

Computer graphic is one of the designer's abilities in creating information and making visual images of a communication or product. As new generation, students of graphic design demands new approach in learning structure and computer software, especially for computer graphic course. Many projects deal with a new area of application of computer, learning should motivate students to solve complex problems and cope with the challenges [6]. In addition to learning technology, in producing visual works, theoretical knowledge has been very important [7]. Computer based education needs to focus on practical oriented learning, because students can work and practice on the same computer, hardware, and software in various types of environments, inside or outside the classroom [8]. Learning computer graphics is a combine of skills [9], such as software for visual concepts, through color, size, 3D, illustration, shading and visual symbol [7]. Changes in technology have influenced students' way of learning computer graphics. Research shows that students bring their own experiences, learning styles, thinking styles, abilities, motivation and creativity into the classroom, this information is important in order to create instructional [10], teacher should pay attention to the digital natives' characteristics when designing courses and materials, and determining the most appropriate teaching methods [11] for students to learn effectively. In order to create meaningful learning, the process needs to be designed base on the condition of students as the subject of learning and the environment where students live, the character of students will be influential in choosing learning strategies [12]. A deep understanding of the problems and needs from student's point of view is the best foundation in creating learning process. Building empathy can be an option to help instructional designer to gain a deeper perspective of student's needs. It also helps to find instruction that fits student's environment, in order to give them the right tools and methods of learning.

The identification of ways students use to process information is needed. However, digging deeper about their prioritized necessity is equally important, so that students can utilize their own strength. One way to do this is by building empathy towards them. Building empathy can be defined as a way to share understanding and experience, finding the ability to identify and understand the situation and feelings of others 
[13]. Study shows the power of empathy strategies through the activity of questioning, recognizing, and listening to assumptions on the part of the learner gives surprising results or awareness [14] and motivates students to be more engaged in the learning process [15]. The purpose of building empathy is to identify design needs aiming at understanding product users, eliminate assumptions by looking for facts, explore more about motivations and thoughts directly from the student's perspective, provide more authentic information, identify learner's characteristics, and find opportunities for designing better learning instruction that is more need based.

Computer instruction system has some gaps such as theory, teaching content and reality [16]. Learning instructional needs to overcome challenges requires a variety of things related to solving related to uncertainty [17]. Teacher, as an instructional designer, needs to create specific conditions to support student learning outcomes [18]. Building empathy means creating instructional that focuses on the needs and understanding of students, seeing the world through their eyes, based on a user centered approach. Furthermore, there is a need to ask the question regarding creating learning instructional, "Who is the design made for?". However, information regarding student's characteristics as digital natives in learning computer graphic design is not adequately represented, especially in private universities in developing countries in Asia. The purpose of this study is to explore learner's characteristics by building empathy towards students, finding their specific needs and criteria of creating learning instructional that are more need-based and future-orientated. The findings of this study will help an instructional designer to recognize the gap and the objective of learning computer graphics and designing instruction with new intervention. This paper provides a theoretical background of uses of empathy approach to identify needs from international literature, student characteristics, learning instruction, and computer graphics courses. The outline of research methodology is followed by presentation and discussion of empirical findings and end with a conclusion that suggest area for recommendation, and further research.

\section{Overview}

This section will explain the overview of theoretical background used in this study. For the purpose of this study, empathy, student characteristic, learning instruction and computer graphic course are used as theoretical overview.

\subsection{Empathy}

Adjusting to the student's needs and expectations, teacher, as the instructional designers, need to be bold in exploring ways to develop types of learning needed in current and future learning approaches. Investigation shows student profiling will helps lecturer to identify suitable activity [19]. This means investigating more information from the students' point of view is needed to build engagement during the instructional development. In this study, the term of empathy is referring to the stage of design thinking. Design thinking is the framework of the creation process to solve 
problems, products, services, systems or strategies that focus on human-centered design [20] to overcome wicked problems or problems that are difficult to solve because of various incomplete information [21]. The Stanford model has five phases or stages of design thinking, which are done through solutions or problem resolutions, these five modes, are: 1) empathizing, 2) defining, 3) ideas, 4) prototypes, and 5) tests [22]. In design thinking, empathy is especially important in the first stage intending to understand user needs, change positions, interacting, making observations, and immersing them in the user's perspective [23].

Empathy is defined as standing in someone else's or seeing through someone else's eyes [23]. Empathy is an important part of human-centered design. Studies found that the role of empathy by getting students involve in the learning design process, opening up more opportunities to get results that suit their needs [24]. Empathy is usually done by teachers in understanding classroom conditions, but sometimes teachers fail to understand. Study shows that a teacher who discovers the power of empathy strategy through activity of questioning, recognizing, and listening to assumptions from the side of students giving results, and surprising awareness [22]. Building empathy is capturing a specific mindset and needs of students; focused on how to help them to achieve their goals. Understand their wants and needs as users in the learning process, by putting them "in their needs" will help teachers designing learning instruction. This study will use an empathy map as a tool to identify and define information from students.

Empathy map is a method used by designers to communicate findings, visualize findings, data collected about users during the research phase in an easily digestible format, with user-centered approach and quickly develop a customer or user profile [25]. Empathy map represent questions that focus on understanding individuals by looking at the world through their eyes, when stakeholders understand their users; they can understand how a small change in design can have a big impact on users [26]. There are several versions about empathy maps, to generate questions, empathy map proposed different areas related to think and feel, see, say and do, hear, pain and gain [27]. This research will only emphasize on the use of empathy map in two areas, namely pain and gain. The pain section is to find fears, frustrations, and obstacles students need to overcome. This information will be used to find out what is stopping them from achieving their goals and desires, such as obstacles or challenges. In the gain section, is comprising all information related to the success students want to achieve, and how they got it. This will also include their goals, desires, and needs; which ease them in their learning process.

\subsection{Students characteristic}

Student characteristics are often defined as the attitudes and personalities that students bring to learning situations. Furthermore, it can also be seen as pain, gain, hope, desire, motivation, skill, which are the goals to be achieved or experienced in a learning process. Some first-year students, as early learners, when transitioning into higher education, they experience academic and social challenges, they may not be familiar with institutional rules or practices and do not have a personal network to ask for 
guidance on how to deal with them [28]. But they have capability when connected with academic content, can contribute to academic learning, self-development, and advancement of scientific disciplines [29]. Research findings show that young people mostly rely on 'imitation' and 'learning by teaching' strategies to learn new skills [30], based on these results; the characteristics of digital natives need to be reviewed according to the conditions experienced. Differentiated learning enables student to work at their optimal speed, provides opportunities to cope with the assignments, increases interest in learning activities, and form positive motives to learn [31]. Building empathy can help to find strength from the student's perspective as a construct of learner characteristics provides opportunities for teaching and learning to be made more personalized, adapted, according to students' needs. Results of this study will provide guidelines in designing learning instruction, finding topics, concepts, or teaching strategies for developing specific instruction student-centered learning features.

\subsection{Learning instruction}

Student-centered education is the most important to optimize learning process and help all students to reach their potential [32]. In this era of competitiveness and increasingly complex challenges, student-centered education is relevantly appropriate to fulfill students' needs to develop their abilities and capabilities [33]. Learning instruction is adjusted to the learning needs and interests of learners. There are four learning factors that need to be considered when developing a learning plan:

1) Content knowledge

2) Skill development

3) Learning attitudes

4) Learning integration [34]

Educators must provide sufficient time to explore those factors to be able to maximize all potentials that benefit students when implementing the learning opportunities [35], it is indicated that designing learning instruction itself is an important learning goal.

To have learning experiences, teachers need to know where the learner's staring point and define student success ends. Identify the gap between the factual conditions of students with what is needed by students

1) Knowledge, in the form of information

2) Skills

3) Motivation

4) Learning environment

5) Communication [36]

will help creating a new approach for instruction, encourages student autonomy and motivation, engages in solving a real-world problem and provides opportunities for them to take control of their own learning [37]. It is important to prepare instructional design that is analyzed from domain content into the components of knowledge 
that students will bring to the course [38]. Learning instruction should facilitate knowledge construct with different forms of scaffolding that more capable from students, and create supportive learning activities [34]. Furthermore, building empathy on learning instruction for the student-centered paradigm can be developed by involving students through listening to their anxiety as input in learning planning. Encourage students to express in the hope that it can help to create a learning experience.

\subsection{Computer graphic design course}

Computer graphics courses enable students to create designs, using digital application, software, techniques and study advances in the field. Students gain learning experience in exploring fundamental concepts and techniques of visual communication designs (image editing and image creation) using computer graphics software. Computer graphics learning in high pace technological environment, it regularly needed to review instructional learning and adjust to attract and engage students [39]. The number of studies on how to teach computer graphics for higher education is still small. Although there are studies found that constructivist pedagogy and didactic guidelines may be useful in teaching computer graphics [40], it is necessary to study the ways of learning that are truly in line with the needs of current students. In order to increase the quality of learning, computer graphics courses need to construct practical teaching systems, improve performance while conventional teaching and learning practice is not sufficient for improving some skill on graphics communication [41]. Today's challenge is how or what should be taught to students, when they can find various information and tutorials on how to use digital application, software, techniques independently. Creating course content, teaching materials, include theory, experiment, operating, and practice methods should facilitate new learning experience for students to explore ideas, and information, and techniques which they cannot be self-learned.

\section{Methodology}

This paper used qualitative research for exploring human problem, using casestudy of a case [42] through interviews, discussions, and documents. This study investigated the student's characteristics in a complex technology environment. A single case was selected in order to get an extensive, deeper insights description [43] understand the perspective from the student's point of view, and find new learning objectives for creating instructional.

The research was conducted in a first-year computer graphic class of a visual communication design school, with Adobe Illustrator software for creating 2D and 3D designs. This school is known to be an institution that uses adequate information technology-based learning model. The class was equipped with a complete computer laboratory sets, with 33 students and a teacher. The study was done in a session of its learning class. 
Data collection was taken from questioners, an interview with the teacher, focus group discussion, and empathy map as one the instrument. The used of questioner is to find basic information about learning habit adapted from aspect of learning factors:

1) Content knowledge

2) Skill development

3) Learning attitudes [34]

Questioner contains questions about student learning habits distributed to all 33 students. Semi-structured interviews were conducted on the teacher to investigate learning condition regarding its difficulties, challenges, and other components. Group discussion with 10 students to explore more information about learning needs from the student's perspective. It began with open ended question discussion; provide opportunities for students to feel free to express their opinions. The last step was filling the empathy map sheet with all students to get all information related to pain and gain in the computer graphic learning.

These approaches were selected because they enabled the researchers to gather and identify important information relating to students' goals and desires, obstacles or challenges. A qualitative descriptive analysis technique is used in this research. The data analysis will be done with the following steps: Organizing, describing the data, presentation of data and data conclusions.

\section{$4 \quad$ Finding and Discussion}

The discussions begin with students' characteristic identification which then proceeds to the results taken from data collection.

\subsection{Identifying students' characteristic}

Questioning, recognizing, and listening are the key to building empathy. When collecting data, these three things become an emphasis on the implementation. First finding reveal the results of the questionnaire about learning habits include:

1) Reasons in choosing the field of visual communication

2) Access to learning resources

3) Habits in reading information

4) Access to communication channels concerning habits as digital natives using visual images, such as pictures or videos [3]

Students choose visual communication because of their self-interest, with percentage response of $77 \%$ this provides opportunities for students to learn more optimally. The interest that grows from students themselves opens the possibility for teachers to use student-centered learning methods in learning instruction. The response of $93 \%$ students has no difficulty in gaining access to learning resources. It shows that students can search for information independently. The majority of students, $76 \%$ likes 
reading and looking for information using visual. All 30 students have no difficulty in accessing technology and information, they stated that it is easy to find visuals or video tutorials online; this result is in line with earlier literature [2] that students from digital native have no difficulty in using complex technology products.

In computer graphics classes there are complex project assignments, and necessitate to be adjusted for students as early learners in the first year of higher education [28]. Focus group discussions use open-ended questions so students as early learners can share what's on their minds with more depth and a lengthier response, express their thoughts and hope that suit their needs learning [24], convey their thoughts and feelings using questions related to information including difficulties, expectations, from the learning factor [34]. The questions were regarding the desired learning experience, things that students want to know more about learning computer graphic. Table 1 explains the information of the discussion result.

Table 1. Focus group discussion result

\begin{tabular}{|c|c|}
\hline Difficulties & Expectation \\
\hline $\begin{array}{l}\text { Exploring ideas } \\
\text { Express feeling } \\
\text { Make a design concept }\end{array}$ & $\begin{array}{l}\text { Good computer graphic technique skill } \\
\text { Good presentation }\end{array}$ \\
\hline Content & Learning environment \\
\hline $\begin{array}{l}\text { Work as professional } \\
\text { Design industry }\end{array}$ & $\begin{array}{l}\text { Feedback from friends } \\
\text { Discussion } \\
\text { Brainstorming }\end{array}$ \\
\hline
\end{tabular}

The result shows that students are interested in more things other than knowing about knowledge contents and skill sets or technique needed to use software of design. Moreover, their enthusiasms in regards of techniques used to operate computer graphic software are vaguely shown. The students are more engaged in things concerning process of designing. These facts are supported by statements collected from an interview with their lecturer saying that in the classroom, the students asked more questions about designing process rather than about computer software techniques. This is due to the existence of various tutorials available online that ease them to learn and explore [1] the technical use of computer software. Therefore, it can be said that the information gap mentioned earlier in this analysis is limited to no existence. Information become means needed by students to perform tasks they need to accomplish [36]. Rather than giving a lecture on techniques to use computer graphic software, it is preferable for lecturer to direct students in exploring process of making a design work. The challenge now is to suitably direct students to choose and to use information they already have on hand as needed. This is where other study skills related to as being a designer are needed.

The last step was filling the empathy map sheet to get a deep understanding about information related to pain and gain in the computer graphic learning [25]. Building empathy is not only concerned with facts about the students (such as their fear, pain, or their like and dislike), it also opened an opportunity to observe from various sides; how to decide learning outcome (for instance, what content students need to master) 
from both sides' students and lecture point of view. Rather than aiming to design for the ideal user, empathic strategies focus on revealing and discovering learning opportunities for students [44]. Reducing subjectivity, avoiding assumptions in finding out about what students should have, knowing what students really need in the learning process.

There are two questions adapted from the empathy map which are 1) pain; fear, frustration, and anxiety in the learning process, and 2) gain; desires, needs, hopes, and dreams. Through these questions obtained a lot of information that is more authentic, even surprising [22] to help and find opportunities for a better learning process. Table 2 below shows information from the empathy map, including numbers of students who revealed the answer result.

Table 2. Empathy map result

\begin{tabular}{|l|c|l|c|}
\hline \multicolumn{1}{|c|}{$\begin{array}{c}\text { Pain } \\
\text { What are their fears, frustration, } \\
\text { and anxieties? }\end{array}$} & Student (n) & \multicolumn{1}{c|}{$\begin{array}{c}\text { Gain } \\
\text { What are their want, needs, hope, } \\
\text { and dreams? }\end{array}$} & Student (n) \\
\hline $\begin{array}{l}\text { Design works are not in line with } \\
\text { expectations }\end{array}$ & 2 & Satisfied with the artwork & 1 \\
\hline Ideation & 2 & Being famous designer & 1 \\
\hline $\begin{array}{l}\text { Afraid of not being able to complete the } \\
\text { task }\end{array}$ & 2 & $\begin{array}{l}\text { Have own platform in creating design } \\
\text { works }\end{array}$ & 2 \\
\hline Time scheduling & 6 & Learn from experienced mentors & 2 \\
\hline Health constraints & 1 & Work at famous agency & 2 \\
\hline Self-confidence & 2 & $\begin{array}{l}\text { Make famous design work, with } \\
\text { YouTube channel }\end{array}$ & 2 \\
\hline Cannot play with friends & 1 & Find passion & 2 \\
\hline Design work is not appreciated & 2 & Having the latest technological device & 3 \\
\hline $\begin{array}{l}\text { Cannot understand the use of Adobe } \\
\text { Illustrator software }\end{array}$ & 1 & $\begin{array}{l}\text { Getting ideas, be imaginative, and } \\
\text { creativity }\end{array}$ & 4 \\
\hline Don't understand design process & 7 & Relax and comfort class & 1 \\
\hline Presentation & 1 & Drawing skill & 1 \\
\hline Don't have appropriate devices & 1 & Learn design process & 7 \\
\hline Learning environment & 2 & Learn about graphic software & 2 \\
\hline
\end{tabular}

Based on these results, there are only three students mentioned the content knowledge, one student specified in the pain section and two students in the gain section, they mention about the use of Adobe Illustrator and graphic software. Most of students are no longer worry about not getting content, but rather how to adapt to the learning process in computer graphics classes. Students expect learning experience that builds their skills and abilities as designer (such as time management, presentation skills, platform in creating design works and design process), improve their thinking skills, and to explore ideas, appreciation or critic in design, using online platform as a learning space and introduction to their design work.

From focus discussion and empathy map result, the ability to transfer knowledge when learning design projects that improve design expertise [45] becomes more important than compiling content knowledge that must be learned. Finding showed that 
there are more gaps in skills and learning environment [36]. Learning need to facilitate students' experiences and prepare them more in regards of:

1) Skill as designer, such as self-confidence, appreciation, scheduling, health

2) Design environment as a context, such as knowing about professional designer, introduce design work online [4], technology devices, design industry

3) Thinking skills related to design process, such ideation, generate design benchmarks, decision making, design concept.

There is a surprising word cited in the empathy map result, that is 'famous'. The definition of the word famous generally means recognized by many people. This word emphasized to student's generation as digital natives, which is reflected in their connectivity level to the online world and engagement in social media conversations, internet, [46] such as followers, likes, comments. As students born into and raised in this digital era, the desire to create, meet or work in a famous place, online platform and social media can be facilitated in the learning process to meet the needs of students in their future.

\subsection{Learning objectives based on student needs}

Building empathy activities help to find various problems and needs faced by students. Computer graphics as one of the capabilities to be a graphic designer, not only requires abilities how to explore visuals through image-making techniques using computer graphic software, but more as practical projects to develop other skills as designers. In creating a computer graphics learning process to be more optimized, it is necessary to be able to combine several approaches to accommodate student learning needs [47].

Regarding the result from building empathy activities, computer graphic course requires a new learning approach. Students have new expectation and interests. The basic skills of the traditional way to learning design are not enough, especially caused by the various needs of its users [48]. This finding has identified that, in establishing a professional graphic designer, design learning should place more consideration on design practice and understandings of the design process, rather than teaching specific technical tools or software that might be different or even changing future industry [49]. The finding suggested new learning objectives on learning computer graphic.

- Emphasize more on design process in the learning of computer graphics, rather than mastering the technical ability to using the software.

- Student need to be made aware of personal skill and abilities as designer.

- Incorporate more thinking skills related to design process.

- Introduce industrial environment of professional designers.

From these results, teachers can improve teaching ability through renewal of learning objectives, and give more focus on developing student's ability as designer, especially for students in the first year, as an adaptation process when transitioning to higher education [28]. 


\subsection{Criteria for learning instructional needed in computer graphic design course}

Furthermore, new learning objectives suggested that learning instruction should be developed in new perspective. Aside from mastering computer graphics technically, there are also skills and ability to use that capacity as tools in design practice. This substantiates previous findings referring to the importance of digital capabilities should go far beyond functional knowledge and skill in using tools [49]. These findings suggest instruction for learning computer graphic needs to apply greater attention to contextual requirements; 1) student-centered, 2) have the current technology mindset, 3) focus on the design practice, and 4) flexible, ability to be easily modified to respond to circumstances or conditions. Pursue new possibilities attached to these characteristics. Generally, from the discussion, below are criteria used in creating learning instruction:

- Introducing computer graphic skills not only in terms of technical use, but also understanding as a design process in practice.

- Provide teaching materials for computer graphic design courses that include theory and practice for digital natives.

- Promote practitioners who work using new graphic software to introduce computer graphic and technology advancement in industry.

- Explore more study skills as designer as early learners that transitioning into higher education

- Facilitate online exhibition using websites or social media

- Help students cope with challenges faced in the ever-changing world.

Learning instruction has a direct effect on learning. A lesson becomes a success or failure depending on students' understanding and ability to recognize what they are supposed to do. This criterion is a challenge for teacher when creating instructional design in operational terms, so novice student can have learning experience of computer graphics.

\section{Conclusion}

This study found that building empathy can be the first step in analyzing student need and characteristics in creating instructional design. Understand need, by questioning, understanding, and listening (thoughts, feelings, hopes) from the student's perspective. The aim is to better understand how students learn amid the quickly changing graphic software and technology. Building empathy has the opportunity to prevent the failure of the design of learning, avoiding the assumption that what is designed by the teacher will be appropriate or preferred by the learner (student), especially for the digital natives. This study shows that involving students as its resource can help to gather the latest and fresher information related to their learning needs. Therefore, students can optimize their studies by precisely directing all of their resources. 
The result of this study indicates that students have no difficulty in accessing and using complex technology; information related to content knowledge in learning computer graphic has been solved by the internet, and this is in accordance with their characteristics as digital native. The challenge is how to direct students using the information that is suitable to their learning needs. As new learners, they also should have study skills related as designer, learning environment that suits their needs in order to build their personal development, enhance their personal skill and abilities as well as thinking skills as a designer. Students not only need to develop computer graphics capabilities technically, but also need to develop the ability to figure out how software tools operate in design practice as implemented in the design industry.

This study has highlighted the importance of a learning environment that suits student's needs, if they learn in the atmosphere as they grow; this gives opportunity for them to own the learning. This finding suggests the following future research on instructional learning that stimulate student's ability that concentrate on designer's skills in their future. Broader discussion about the word 'famous' from student's perspective related to digital information and technologies needs to be explored further. Students desire to introduce their design work online or using digital exhibition can be facilitated in the learning process as a way of disseminating their work as portfolios.

The finding might not be representative for other subject, because each program has different characteristics. But, building empathy can be applicable and implement to the multidisciplinary in several fields such as social, humanities, or engineering. This study can be the first step toward enhancing the understanding of creating learning instruction for digital natives.

\section{Acknowledgement}

The author's gratitude goes Universities Negeri Surabaya that has provided research opportunities. The author also graces the stake holders who provided the opportunity to conduct this research in one of the computer graphic design courses in the Visual Communication Design program.

\section{$7 \quad$ References}

[1] A. W. Bates, teaching in a digital age; Guidelines for designing teaching ang learning, Columbia: University of British Columbia, 2016.

[2] M. Prensky, "Digital natives, digital immigrants' part 1," On the Horizon, 9 (5), pp. 1-6, 2001.

[3] R. A. Berk, "Teaching strategies for the next generation," Transformative Dialogues: Teaching \& Learning Journal, 3(2), pp. 1-23, 2006.

[4] T. Teo, K. Yurdaku, I. and Ö. F. Ursavaş, "Exploring the digital natives among pre-service teachers in Turkey: a cross-cultural validation of the Digital Native Assessment Scale," Interactive Learning Environments, pp. 1-14, 2014. https://doi.org/10.1080/10494820.2014.9 $\underline{80275}$

[5] E. Helsper and R. Eynon, "Digital natives: Where is the evidence?" British Educational Research Journal, 36(3), pp. 503-520, 2010. https://doi.org/10.1080/01411920902989227 
[6] J. Katona and A. Kovari, "A Brain-Computer Interface Project Applied in Computer Engineering," IEEE Transactions on Education,59 (4), pp. 319-326, 2016. https://doi.org/10. $\underline{1109 / \text { te. } 2016.2558163}$

[7] J. Huang, "Research on the computer graphic design and visual communication design," Advance Material Research, 1055, pp. 342-345, 2014. https://doi.org/10.4028/www.scienti fic.net/amr.1055.342

[8] M. Cifredo-Chacón, J. M. Guerrero-Rodríguez and A. Quirós-Olozábal, "Computer architecture and FPGAs: A Learning-by-doing methodology for digital-native students," Computer Architecture and FPGAs, pp. 464-470, 2014. https://doi.org/10.1002/cae.21617

[9] T. Suselo, B. C. Wünsche and A. Luxton-Reilly, "Technologies and tools to support teaching and learning computer graphics: A literature review," in Twenty-First Australasian Computing Education Conference (ACE'19), Sydney, NSW, Australia., 2019. https://doi. org/10.1145/3286960.3286972

[10] A. Nordina, "Students' Characteristics as Indicator for Effective Teaching," Jurnal Teknologi, 63 (2), pp. 21-26, 2013.

[11] M. Akçayır, H. Dündar and G. Akçayır, "What makes you a digital native? Is it enough to be born after 1980?" Computers in Human Behavior, 60 , pp. 435-440, 2016. https://doi. org/10.1016/j.chb.2016.02.089

[12] N. S. Degeng and P. D. D. Degeng, Ilmu pembelajaran; Klasifikasi variabel untuk pengembangan teori dan penelitian, Yogyakarta: Yayasan Taman Pustaka Kristen Indonesia, 2013.

[13] F. Miller and J. Wallis, "Social interaction and the role of empathy in information and knowledge management: A literature review," Journal of Education for Library and Information Science, 52 (2), pp. 122-132, 2011.

[14] D. Henriksen, C. Richardson and R. M., "Design thinking: A creative approach to educational problems of practice," Thinking Skills and Creativity, 26, p. 140-153, 2017. https:// doi.org/10.1016/j.tsc.2017.10.001

[15] C. Carmel-Gilfilen and M. Portillo, "Designing with empathy: Humanizing narratives for inspired healthcare experiences," Health Environments Research \& Design Journal, 9 (2), pp. 130-146, 2016. https://doi.org/10.1177/1937586715592633

[16] H. Guo, "Application of a computer-assisted instruction system based on constructivism," International Journal of Emerging Technologies in Learning (iJET), 13(4), pp. 33-44, 2018. https://doi.org/10.3991/ijet.v13i04.8468

[17] E. D. Helsinki and T. Leinonen, "Design thinking and collaborative learning," Comunicar Media Education Research Journal, 21, pp. 107-116, 2014.

[18] W. A. Sugar and L. L. Warren, "Promoting a teacher/leader-designer perspective for public school teachers," Action in Teacher Education, pp. 30-37, 2003. https://doi.org/10.1080/0 1626620.2003 .10734440

[19] M. Man, M. H. N. Azhan and W. M. A. F. W. Hamzah, "Conceptual model for profiling student behaviour experience in e-learning," International Journal of Emerging Technologies in Learning (iJET), 14(21), pp. 163-175, 2019. https://doi.org/10.3991/ijet.v14i21.109 $\underline{36}$

[20] T. Brown, "Design thinking," Harvard Business Review, pp. 84-92, 2008.

[21] F. E. H. M. Smulders, K. Dorst and P. E. Vermaas, "Applying design thinking elsewhere: Organizational context matters," in Proceedings of the 19th DMI: Academic design management conference, Boston, 2014.

[22] D. Henriksen, C. Richardson and R. Mehta, "Design thinking: A creative approach to educational problems of practice," Thinking Skills and Creativity Vol 26, p. 140-153, 2017. https://doi.org/10.1016/j.tsc.2017.10.001 
[23] R. Curedale, Design thinking: Process and methods, USA: Design Community College Incorporated, 2016.

[24] A. Kutlu and L. Coskun, "The role of empathy in the learning process and its fruitful outcomes: A comparative study," Journal of Educational and Social Research, 4(2), pp. 203207, 2014. https://doi.org/10.5901/jesr.2014.v4n2p203

[25] D. Gray, S. Brown and J. Macanufo, Gamestorming - A playbook for innovators, rulebreakers and changemakers, Sebastopol CA: O'Reilly Media, Inc., 2010.

[26] H. M. Bratsberg, ""Empathy Maps of the FourSight Preferences" Creative Studies Graduate Student Master's Projects. 176.," Buffalo State Collage, New York, 2012.

[27] Royal Civil Service Commission, July 2017. [Online]. Available: https://www.rcsc.gov.bt/wp-content/uploads/2017/07/dt-guide-book-master-copy.pdf. [Accessed 20 September 2019].

[28] E. T. Pascarella, C. T. Pierson, G. C. Wolniak and P. T. Terenzini, "First-Generation college students' additional evidence on college experiences and outcomes," The Journal of Higher Education, 75(3), pp. 249-284, 2004. https://doi.org/10.1353/jhe.2004.0016

[29] J. Ives and M. Castillo-Montoya, "First-Generation college students as academic learners: A systematic review," Review of Educational Research, XX(X), p. 1-40, 2020. https://doi. org/10.3102/0034654319899707

[30] M.-J. Masanet, M. Guerrero-Pico and M.-J. Establés, "From digital native to digital apprentice. A case study of the transmedia skills and informal learning strategies of adolescents in Spain," Learning, Media and Technology, pp. 1-14, 2019. https://doi.org/10.1080/ 17439884.2019 .1641513

[31] Z. Kopeyev, A. Mubarakov, J. Kultan, G. Aimicheva and Y. Tuyakov, "Using a personalized learning style and Google Classroom technology to bridge the knowledge gap on computer science," International Journal of Emerging Technologies in Learning (iJET), 15(2), pp. 218-229, 2020. https://doi.org/10.3991/ijet.v15i02.11602

[32] C. M. Reigeluth, B. J. Beatty and R. D. Myers, Instructional-design theories and models volume IV, historicity: The learner-centered paradigm of education, New York: Routledge, 2016. https://doi.org/10.1007/s11528-017-0193-1

[33] T. Friedman, The world is flat: A brief history of the twenty-first century, New York: Farrar, Straus \& Giroux, 2007.

[34] Y.-L. Lu and C.-W. Wu, "An integrated evaluation model of teaching and learning," Journal of University Teaching \& Learning Practice, 15(3), pp. 1-17, 2018.

[35] A. J. Auerbach, M. Higgins, P. Brickman and T. C. Andrews, "Teacher knowledge for active-learning instruction: Expert-novice comparison reveals differences," CBE-Life Sciences Education, pp. 1-14, 2018. https://doi.org/10.1187/cbe.17-07-0149

[36] J. Dirksen, Design for how people learn, Berkeley, CA: New Riders, 2012.

[37] J. C. Chen, "Designing online project-based learning Instruction for EFL learners: A WebQuest approach," MEXTESOL Journal, 43(2), pp. 1-6, 2019.

[38] K. R. Koedinger, A. T. Corbett and C. Perfetti, "The Knowledge-Learning-Instruction framework: Bridging the Science-Practice chasm to enhance robust student learning," Cognitive Science, pp. 1-42, 2012. https://doi.org/10.1111/j.1551-6709.2012.01245.x

[39] D. Balreira, M. Walter and D. Fellner, "What we are teaching in introduction to computer graphics," in Eurographics Proceedings, Lyon, France, 2017.

[40] G. Taxen, "Teaching computer graphics constructively," Computers \& Graphics, 28, p. 393-399, 2004. https://doi.org/10.1016/j.cag.2004.03.006

[41] P. J. Kok and A. Bayaga, "Enhancing graphic communication and design student teachers' spatial visualisation skills through 3D solid computer modelling," African Journal of Re- 
search in Mathematics, Science and Technology Education, 23(1), pp. 52-63, 2019. https:// doi.org/10.1080/18117295.2019.1587249

[42] J. W. Creswell, Research design: Qualitative, quantitative, and mixed methods approaches, Singapore: SAGE Publications, Inc., 2014.

[43] R. K. Yin, Case study research and applications: : Design and methods. Sixth edition, Los Angeles: SAGE Publications, Inc., 2018.

[44] D. McDonagh and J. Thomas, "Rethinking design thinking: Empathy supporting innovation," Australasian Medical Journal - Health and Design 1, 3(8), pp. 458-464, 2010. https:// doi.org/10.4066/amj.2010.391

[45] G. Ellmers and M. Foley, "Developing expertise: Benefits of generalising learning from the graphic design project," International Journal of Art \& Design Education, pp. 1-15, 2019. https://doi.org/10.1111/jade. 12260

[46] S.-T. Yong, "Digital native students: Gender differences in mathematics and gaming," International Journal of Virtual and Personal Learning Environments, 7(2), pp. 13-26, 2017. https://doi.org/10.4018/ijvple.2017070102

[47] M. Tovey, Design pedagogy: Developments art and design education, New York: Routledge, 2015.

[48] R. Curedale, Service design: Pocket guide, Topanga CA: Design Community College Inc., 2013.

[49] A. Crosby, K. Pham, J. F. Peterson and T. Lee, "Digital work practices: Affordances in design education," International Journal of Art \& Design Education, pp. 1-16, 2019. https:// doi.org/10.1111/jade.12231

[50] M. S. Kerr, K. Rynearson and M. C. Kerr, "Student characteristics for online learning success," Internet and Higher Education, 9, p. 91-105, 2006. https://doi.org/10.1016/j.iheduc. $\underline{2006.03 .002}$

\section{Authors}

Siti Nurannisaa P.B. is a Lecturer, Researcher, at Universities Tarumanagara, J1. LetJen S. Parman No.1 Jakarta, Indonesia. She is now a Doctoral student at Universities Negeri Surabaya, Jl. Lidah Wetan Surabaya, Indonesia. (e-mail: sitip@fsr d.untar.ac.id, siti.17070996001@ mhs.unesa.ac.id).

Mustaji. Professor, Researcher, at Universities Negeri Surabaya, Jl. Lidah Wetan Surabaya, Indonesia. (e-mail: mustaji@unesa.ac.id).

Bachtiar S. Bachri. Doctor, Researcher, at Universities Negeri Surabaya, Jl. Lidah Wetan Surabaya, Indonesia. (e-mail: bachtiarbachri@unesa.ac.id).

Florens Debora Patricia. Lecturer, Researcher, at Universities Dinamika Surabaya, Raya Kedung Baruk No.98 Surabaya, Indonesia. (e-mail: florens@ dinamik a.ac.id)

Article submitted 2020-03-20. Resubmitted 2020-07-19. Final acceptance 2020-07-22. Final version published as submitted by the authors. 